\title{
Isolation and analysis of immune complexes
sera of patients with polymyalgia rheumatica and giant cell arteritis
}

\author{
A J SMITH, V KYLE, T E CAWSTON, AND B L HAZLEMAN \\ From the Rheumatology Research Unit, Addenbrooke's Hospital, Hills Road, Cambridge
}

SUMMARY Serum samples were obtained from patients with polymyalgia rheumatica (PMR $n=10)$ or giant cell arteritis (GCA; $=7)$, or both. Samples were taken either before treatment o within one week of starting prednisolone. Immune complexes (IC) were concentrated b $\mathbb{B}_{0}$ polyethylene glycol (PEG) precipitation then purified with either IgG anti-C1q-Sepharose or IgG anti-C3c-Sepharose. Complex components were separated by sodium dodecyl sulphate (SDSF gradient polyacrylamide gel electrophoresis then transferred to nitrocellulose by Wester blotting. Identification of proteins was carried out using specific antisera. All the IC containe $\operatorname{IgM}$ ( $\mu$ chain), some contained IgA ( $\alpha$ chain), and IgG ( $\gamma$ chain). C1r, C1s, C1q, C3, C4, and $\xi_{0}$ reactive protein $(\mathrm{CRP})$, where tested, were found in most but not all IC. The occurrence o. properdin, factor $B, \alpha_{2}$ macroglobulin $\left(\alpha_{2} M\right)$, factor $H(\beta 1 H), C 1$ esterase inhibitor, and C4 binding protein was also investigated. Immune complexes in PMR and GCA differed from those previously characterised in rheumatoid arthritis (RA) ${ }^{1}$ purified by anti-C1q-Sepharose whic contained immunoglobulins and $\mathrm{Clq}$ only. No properdin or factor B were detected in RA I@ purified with either anti-C1q-Sepharose or anti-C3c-Sepharose.

Polymyalgia rheumatica (PMR) and giant cell arteritis (GCA) frequently occur together in those over 50 years old. In PMR there is characteristic shoulder and pelvic girdle pain and morning stiffness. GCA commonly causes temporal headaches and visual problems but is associated with varying clinical syndromes which reflect the vessels involved. Both are associated with a raised erythrocyte sedimentation rate (ESR). The pathogenesis of the condition is unclear, but studies suggest there may be an immunological basis. The serum of patients with GCA contains raised IgG, total complement, C3, and $C 4^{23}$ and ESR and CRP. Circulating IC have been investigated by several groups using various IC assays. ${ }^{4-7}$ Park et al using the PEG CC assay demonstrated raised IC levels in $44 \%$ of active untreated patients with PMR and GCA and in 23\% of inactive treated cases. ${ }^{4}$ The ${ }^{125} \mathrm{I}-\mathrm{C} 1 \mathrm{q}$ binding assay and PEG C4 assay also detected IC, but the ${ }_{125}$ I conglutinin binding assay did not. Espinoza et al using the Raji cell assay demonstrated raised IC

Accepted for publication 9 January 1987. Correspondence to Miss A J Smith, Rheumatology Research Unit, Addenbrooke's Hospital, Hills Road, Cambridge CB2 2QQ. levels in over $90 \%$ of patients. ${ }^{5} \mathrm{~A}$ solid phase $\mathrm{C} 1 \frac{\mathrm{P}}{\mathrm{q}}$ enzyme linked immunosorbent assay used by

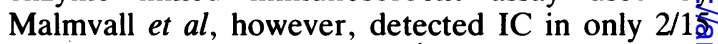
cases of GCA investigated. ${ }^{6}$ Immunofluorescen studies of temporal artery biopsy specimens fror patients with active arteritis show positive staining for immunoglobulins and the third component of complement. .10 $^{-10}$ This could represent antibod binding to an arterial cell wall antigen or IE deposition from the blood.

Immune complexes are a heterogeneous popula․ tion with varying sizes, immunoglobulin composis tion, and complement fixing abilities. The variations in composition affect removal, deposition, and the possible pathological activities of immune comv plexes. Each IC assay detects the presence different components of the complex and therefore may reflect the presence of different IC populationsD A knowledge of the nature and source of circulating IC in PMR/GCA may improve our understanding o尹 the pathogenesis of the condition.

The aim of this study was to determine the composition of IC, where present, in PMR an GCA sera. Since the properties of IC depend on the immunoglobulins and complement components 
contained in the complexes, identification of components may increase our understanding of the nature of the disease.

\section{Patients and methods}

PATIENTS

Fifteen patients with active untreated PMR/GCA were included in the study. All fulfilled the diagnostic criteria of Jones and Hazleman. ${ }^{11}$ Nine had PMR and six GCA, four of whom also had features of PMR. Only one patient was male. The mean age at onset was 68 years (range 52-81). Temporal artery biopsies were carried out in nine cases, and five showed the histological changes of GCA. Seventeen samples of sera were obtained and IC measured using three assays: $\mathrm{C} 1 \mathrm{q}$ binding assay, ${ }^{12}$ PEG complement consumption assay, ${ }^{13}$ and the PEG C4 assay. ${ }^{14}$ IC levels were raised in at least two of the three assays.

PREPARATION OF IMMUNE COMPLEXES

The IC in two aliquots $(750 \mu \mathrm{l})$ from each sample were concentrated by overnight precipitation at $4^{\circ} \mathrm{C}$ with an equal volume of $6 \%$ PEG in $0.1 \mathrm{M}$ borate buffer $\mathrm{pH} 8.3,75 \mathrm{mM} \mathrm{NaCl}$. The precipitate was collected by centrifugation at $2000 \mathrm{~g}$ for $10 \mathrm{~min}$ at $4{ }^{\circ} \mathrm{C}$ and then washed twice with $1.0 \mathrm{ml} 3 \%$ PEG. The precipitate was dissolved in $1.0 \mathrm{ml}$ complement fixation diluent.

IC were then isolated by incubation of an aliquot with $300 \mu \mathrm{l}$ of 1:5 suspension of either anti-C1qSepharose or anti-C3c-Sepharose for two hours at $22^{\circ} \mathrm{C}$. $^{1}$ The Sepharose bound complex was washed with complement fixation diluent, then $500 \mu \mathrm{l}$ of 0.5 M TRIS (trometamol) $\mathrm{HCl}$ buffer $\mathrm{pH} 6 \cdot 8$ containing $2 \cdot 5 \%(w / v)$ SDS, $8 \%$ (v/v) glycerol, $0 \cdot 01 \%(w / v)$ bromophenol blue, and $20 \mathrm{mM}$ dithiothreitol was added, heated at $100^{\circ} \mathrm{C}$ for three minutes, and then loaded onto an SDS-polyacrylamide gel.

SDS GRADIENT POLYACRYLAMIDE GEL

ELECTROPHORESIS (PAGE)

The gels $(125 \times 140 \times 0.75 \mathrm{~mm})$ contained $10-22 \%$ total acrylamide gradient with $2.5 \%$ (w/v) $N, N$ methylenebisacrylamide and an upper gel containing $4.5 \%$ total acrylamide and $2.5 \% \quad N, N$ methylenebisacrylamide and were polymerised by $0.017 \%(\mathrm{w} / \mathrm{v})$ ammonium persulphate and $0.015 \%$ (v/v) $N, N, N^{\prime}, N^{\prime}$-tetramethylethylenediamine. The upper gel had three wells, the two end wells were $5 \times 20 \mathrm{~mm}$ and the centre well $115 \times 20 \mathrm{~mm}$. The buffer system used was as described by Laemmli and Favre. ${ }^{15}$

Two gels were run in parallel using the LKB 2001 vertical electrophoresis apparatus. The centre wells were loaded with IC purified by either anti-C1qSepharose or anti-C3c-Sepharose treated with SDS/DTT as described. ${ }^{125}$ I standards ${ }^{16}$ containing phosphorylase $A$ (relative molecular mass $(\mathrm{Mr})=$ $100000)$, transferrin $(\mathrm{Mr}=78000)$, bovine serum albumin ( $\mathrm{Mr}=68000)$, ovalbumin $(\mathrm{Mr}=43000)$, carbonic anhydrase $(\mathrm{Mr}=29000)$, soya bean trypsin inhibitor (24 000), and $\alpha$ lactalbumin $(\mathrm{Mr}=14000)$ were loaded into the outside wells. Electrophoresis was carried out at $150 \mathrm{~V}$ until the marker dye reached the bottom of the gels.

A $2 \mathrm{~cm}$ strip of each gel containing one of the standard wells was removed, fixed in $40 \%(\mathrm{w} / \mathrm{v})$ trichloroacetic acid, stained in $0.5 \%(\mathrm{w} / \mathrm{v})$ Coomassie brilliant blue $\mathrm{G}$ in $40 \%(\mathrm{v} / \mathrm{v})$ methanol and $5 \%$ $(\mathrm{v} / \mathrm{v})$ acetic acid, ${ }^{17}$ destained, and dried onto filter paper.

TRANSFER TO NITROCELLULOSE

The unfixed portion of each gel was placed in transfer buffer ( $25 \mathrm{mM}$ TRIS, $192 \mathrm{mM}$ glycine, $20 \%$ $(\mathrm{v} / \mathrm{v})$ methanol) for $10 \mathrm{~min}$ before being placed in the plastic holder with a $0.2 \mu \mathrm{m}$ nitrocellulose sheet (Schleicher and Schuell, Anderman \& Co Ltd, Kingston-Upon-Thames, Surrey, UK). The nitrocellulose was marked with the sample identification, gel orientation, and position of the standards. Transfer was carried out in a Bio-Rad transblot cell at $0 \cdot 1 \mathrm{~A}$ overnight. ${ }^{18}$

Unoccupied sites on the nitrocellulose were blocked using a buffer ( $50 \mathrm{mM}$ TRIS/ $\mathrm{HCl}, \mathrm{pH} 7 \cdot 2,5$ $\mathrm{mM}$ ethylenediaminetetra-acetate, $150 \mathrm{mM} \mathrm{NaCl}$, $0.05 \%$ Nonidet $\mathrm{P} 40,0.02 \% \quad \mathrm{NaN}_{3}$ ) containing $0.25 \%(w / v)$ gelatin for a minimum of five hours at $4^{\circ} \mathrm{C}$.

IDENTIFICATION OF PROTEINS

Strips $(6 \mathrm{~mm})$ of nitrocellulose were cut avoiding the standards position. Individual strips were incubated in $5 \mathrm{ml}$ of different specific antisera diluted 1:100 in blocking buffer for one hour at $4^{\circ} \mathrm{C}$. A plastic box $(280 \times 150 \times 40 \mathrm{~mm})$ with compartments $20 \times 150 \times 40$ $\mathrm{mm}$ (Engineering and Design Plastics, Cherry Hinton, Cambridge, UK) was used. The strips were washed with five changes of blocking buffer.

When the antisera had been raised in goats these strips were incubated in rabbit antigoat antisera (Atlantic antibodies, American Hospital Supplies UK Ltd) which had been passed through a human IgG-Sepharose column and then washed as before.

All the strips were incubated in ${ }^{125} \mathrm{I}$ goat antirabbit antiserum (Atlantic antibodies). $3.7 \mathrm{MBq}$ was used in the labelling of approximately $3.5 \mathrm{mg}$ of protein $^{16}$ and was then diluted to $7 \times 10^{5} \mathrm{cpm} / \mathrm{ml}$. The strips were washed, aligned with the piece of nitrocellulose containing the ${ }^{125} \mathrm{I}$ standards, and autoradiographed at $-70^{\circ} \mathrm{C}$ overnight. 

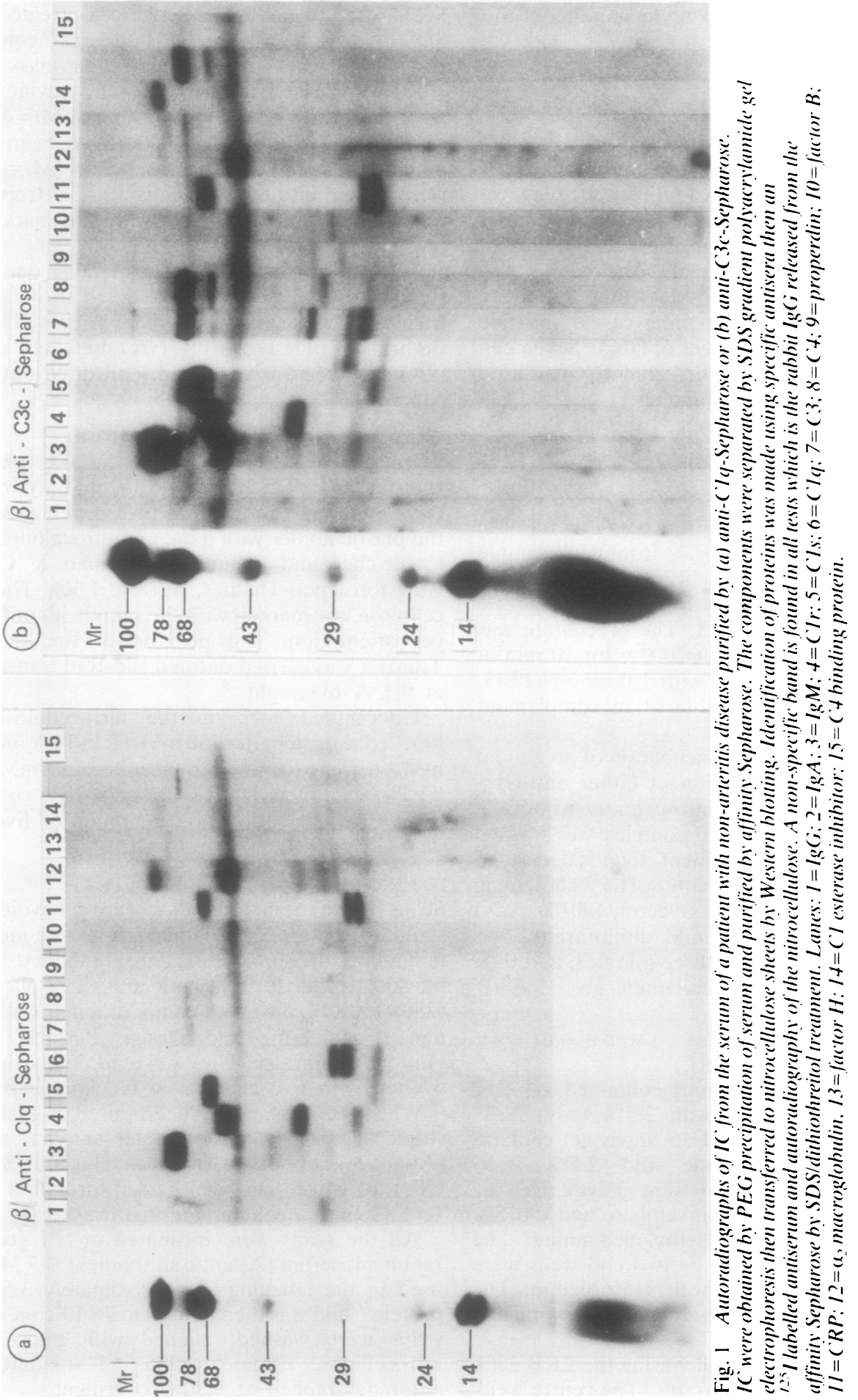

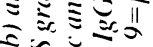

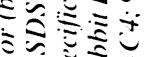
에 $\stackrel{\Xi}{\Xi}$

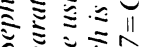

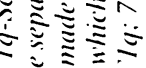

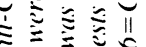

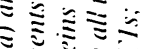
ำ ำำ

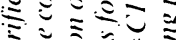

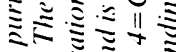

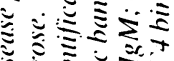
要:

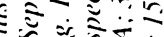

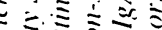

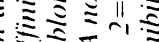

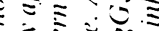

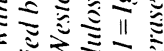

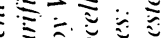

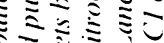

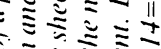

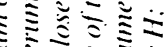

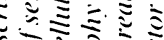
$\mathrm{2}$

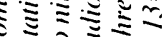

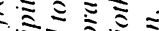

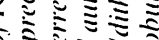

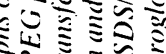

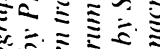

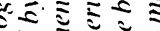

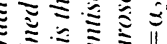
高 칯

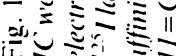


Initially, 10 specific antisera were used: rabbit antihuman IgG and C1q (Dako Patts, Dako Ltd, High Wycombe, UK), and C3c (The Behring Corporation) and goat antihuman IgA, IgM, C1r, $\mathrm{C} 1 \mathrm{~s}, \mathrm{C} 4$, properdin, properdin factor B (Atlantic

Table 1 Identification of proteins on nitrocellulose blots using specific antisera

\begin{tabular}{lcc}
\hline Antiserum to: & $\begin{array}{l}\text { Anti-Clq- } \\
\text { Sepharose }\end{array}$ & $\begin{array}{l}\text { Anti-C3c- } \\
\text { Sepharose }\end{array}$ \\
\hline$n=17$ & & \\
IgG & 3 & 9 \\
IgA & 7 & 17 \\
IgM & 17 & 13 \\
C1r & 16 & 14 \\
C1s & 16 & 14 \\
C1q & 17 & 16 \\
C3 4 & 14 & 5 \\
Properdin & 13 & 3 \\
Factor B & 4 & \\
$n=10$ & 0 & 9 \\
C reactive protein & 10 & 2 \\
$\alpha_{2}$ Macroglobulin & 7 & 4 \\
Factor H & 3 & 3 \\
C1 esterase inhibitor & 5 & 0 \\
C4 binding protein & 0 & \\
\hline
\end{tabular}

IC precipitated by PEG from serum were purified using either anti$\mathrm{Clq}$ - or anti-C3c-Sepharose. The components were separated by SDS gradient PAGE then transferred to nitrocellulose by Western blotting. Proteins were identified using specific antisera and an ${ }^{125} I$ labelled probe. The numbers represent the number of samples which gave positive, i.e., visible, bands on autoradiography of the nitrocellulose sheets. antibodies). Then six additional antisera were used: goat antihuman $\mathrm{C}$ reactive protein, $\alpha_{2}$ macroglobulin, factor $\mathrm{H}(\beta 1 \mathrm{H}), \mathrm{C} 1$ esterase inhibitor, and rabbit antihuman $\mathrm{C} 4$ binding protein (Miles Scientific Ltd, UK).

\section{Results}

The dried gels had very few visible protein bands after staining with Coomassie brilliant blue. Individual proteins were identified using specific antiserum and an ${ }^{125}$ I labelled probe after Western blotting (Fig. 1). The relative molecular mass of the proteins was calculated from the autoradiographs by reference to the mobility of the ${ }^{125}$ I labelled standards. A number of positive staining samples were identified (Table 1), and where multiple protein bands were present this is shown in Table 2 . The overall results are shown in Table 1, where the number of positive samples identified is shown for both the anti-C1q-Sepharose and the anti-C3cSepharose adsorbents. Minor differences were observed, but in general the results for either adsorbent were similar. In some samples differences were observed in both the number or size of protein bands identified. For example 11/17 samples had three protein bands identified with the $\mathrm{Clq}$ antiserum (Mr 37 000, Mr 32 500, and Mr 24 500) (see lane 6, Fig. 1), whereas the other six samples had only either one or two of these protein bands visible. Similarly, multiple protein bands were observed on

Table 2 Identification of protein subunits with antiserum to CIr, CIs, CIq, C3 and C4 on Western blotting of IC from the serum of patients with polymyalgia rheumatica or giant cell arteritis, or both $(n=7)$, or polymyalgia rheumatica only $(n=10)$

\begin{tabular}{|c|c|c|c|c|c|}
\hline \multirow[t]{2}{*}{ Antiserum to: } & \multirow[t]{2}{*}{ No of bands } & \multicolumn{2}{|l|}{$P M R / G C A$} & \multicolumn{2}{|l|}{$P M R$} \\
\hline & & $\begin{array}{l}\text { Anti-Clq- } \\
\text { Sepharose }\end{array}$ & $\begin{array}{l}\text { Anti-C3c- } \\
\text { Sepharose }\end{array}$ & $\begin{array}{l}\text { Anti-CIq- } \\
\text { Sepharose }\end{array}$ & $\begin{array}{l}\text { Anti-C3c- } \\
\text { Sepharose }\end{array}$ \\
\hline $\mathrm{Clr}$ & $\begin{array}{l}1 \\
2 \\
\text { Total }\end{array}$ & $\begin{array}{l}1 \\
5 \\
6\end{array}$ & $\begin{array}{l}4 \\
2 \\
6\end{array}$ & $\begin{array}{l}0 \\
9 \\
9\end{array}$ & $\begin{array}{l}1 \\
7 \\
8\end{array}$ \\
\hline Cls & $\begin{array}{l}1 \\
2 \\
\text { Total }\end{array}$ & $\begin{array}{l}4 \\
2 \\
6\end{array}$ & $\begin{array}{l}4 \\
0 \\
4\end{array}$ & $\begin{array}{r}5 \\
5 \\
10\end{array}$ & $\begin{array}{r}7 \\
3 \\
10\end{array}$ \\
\hline Clq & $\begin{array}{l}1 \\
2 \\
3 \\
\text { Total }\end{array}$ & $\begin{array}{l}3 \\
2 \\
2 \\
7\end{array}$ & $\begin{array}{l}4 \\
1 \\
0 \\
5\end{array}$ & $\begin{array}{r}1 \\
0 \\
9 \\
10\end{array}$ & $\begin{array}{l}4 \\
1 \\
4 \\
9\end{array}$ \\
\hline $\mathrm{C} 3$ & $\begin{array}{l}1 \\
2 \\
3 \\
4 \\
5 \\
7 \\
9\end{array}$ & $\begin{array}{l}4 \\
1\end{array}$ & $\begin{array}{l}1 \\
5 \\
1\end{array}$ & $\begin{array}{l}3 \\
4 \\
1 \\
1\end{array}$ & $\begin{array}{l}1 \\
5 \\
1 \\
1 \\
1\end{array}$ \\
\hline C4 & $\begin{array}{l}\text { Total } \\
1 \\
2 \\
3 \\
5 \\
\text { Total }\end{array}$ & $\begin{array}{l}5 \\
3\end{array}$ & $\begin{array}{l}7 \\
2 \\
1 \\
3\end{array}$ & $\begin{array}{r}9 \\
7 \\
2 \\
1 \\
10\end{array}$ & $\begin{array}{l}9 \\
4 \\
2 \\
2 \\
1 \\
9\end{array}$ \\
\hline
\end{tabular}

The numbers represent samples with positive staining. 
Table 3 Identification of proteins on nitrocellulose blots (as Table 1) with the patients' serum classified as giant cell arteritis or polymyalgia rheumatica

\begin{tabular}{|c|c|c|c|c|}
\hline \multirow[t]{2}{*}{ Antiserum to: } & \multicolumn{2}{|l|}{$G C A$} & \multicolumn{2}{|l|}{$P M R$} \\
\hline & $\begin{array}{l}\text { Anti-Clq- } \\
\text { Sepharose }\end{array}$ & $\begin{array}{l}\text { Anti-C3c- } \\
\text { Sepharose }\end{array}$ & $\begin{array}{l}\text { Anti-CIq- } \\
\text { Sepharose }\end{array}$ & $\begin{array}{l}\text { Anti-C3c- } \\
\text { Sepharose }\end{array}$ \\
\hline & $(n=7)$ & $(n=7)$ & $(n=10)$ & $(n=10)$ \\
\hline IgG & 1 & 0 & 2 & 2 \\
\hline $\operatorname{IgA}$ & 2 & 2 & 5 & 7 \\
\hline IgM & 7 & 7 & 10 & 10 \\
\hline C1r & 7 & 6 & 9 & 8 \\
\hline C1s & 6 & 4 & 10 & 10 \\
\hline $\mathrm{Clq}$ & 7 & 5 & 10 & 9 \\
\hline $\mathrm{C} 3^{1}$ & 5 & 7 & 9 & 9 \\
\hline C4 & 3 & 3 & 10 & 9 \\
\hline Properdin & 1 & 1 & 3 & 4 \\
\hline \multirow[t]{2}{*}{ Factor B } & 0 & 1 & 0 & 2 \\
\hline & $(n=5)$ & $(n=5)$ & $(n=5)$ & $(n=5)$ \\
\hline $\mathrm{C}$ reactive protein & 5 & 5 & 5 & 4 \\
\hline$\alpha_{2}$ Macroglobulin & 3 & 2 & 4 & 0 \\
\hline Factor $\mathrm{H}$ & 1 & 1 & 2 & 3 \\
\hline \multicolumn{5}{|l|}{ C1 esterase } \\
\hline inhibitor & 1 & 0 & 4 & 3 \\
\hline $\mathrm{C} 4$ binding protein & 0 & 0 & 0 & 0 \\
\hline
\end{tabular}

the immunoblots for other complement components such as $\mathrm{C} 1 \mathrm{r}, \mathrm{C} 1 \mathrm{~s}, \mathrm{C} 3$, and $\mathrm{C} 4$, and the relative numbers identified and sizes are shown in Table 2. Six additional antisera were used to investigate a further 10 immunoblot pairs (Table 1 ). $\mathrm{C}$ reactive protein (CRP) was present in all the sera (except one) tested, but no $\mathrm{C} 4$ binding protein $(\mathrm{C} 4 \mathrm{bp})$ was identified. The anti-C1q-Sepharose IC showed positive staining for $\alpha_{2}$ macroglobulin in $7 / 10$ samples, factor $\mathrm{H}$ in $3 / 10$ samples, and $\mathrm{C} 1$ esterase inhibitor in $5 / 10$ samples. Similar results are shown for the anti-C3c-Sepharose IC (Table 1).

Table 3 separates the patients' samples into those with polymyalgia rheumatica alone $(n=10)$ and those with giant cell arteritis $(n=7)$ and then examines the relative distribution of the various immune complex components. Few differences were seen in the components which were often present, e.g., IgM and C1r, and where some differences occurred the numbers were too small for any firm conclusions to be drawn.

\section{Discussion}

Immunoglobulins and complement deposits have been demonstrated in the media and adjacent to the internal elastic lamina in some involved temporal arteries. ${ }^{10}$ It is not known, however, whether such deposits were the result of passive deposition of immune complexes from the circulation or from the combination of specific antibodies with antigens in situ. Sera from patients with giant cell arteritis or polymyalgia rheumatica, or both, have been found to contain increased levels of circulating immune complexes. ${ }^{4}$ Although there was not a high cor ? relation between immune complex levels and disease activity, isolation and analysis of the immune complex may lead to further understandin $\$$ of this disorder.

Circulating immune complexes are frequentl $\vec{\phi}$ detected in patients with inflammatory disorderso and characterisation of the immune complex anti? gens has been carried out in order to identif $\vec{\phi}$ antigens that may elicit the inflammatory reaction i $\overrightarrow{\mathrm{a}}$ affected tissues. Several investigators have attempte $\$$ to identify immune complex antigens in inflammav tion. ${ }^{19}$ 20 We have for the first time analyse $\$$ immune complex preparations from patients with giant cell arteritis.

In this study we have used a new and rapi市 method for the analysis of immune complexeso which allows small volumes of sera to be processed and the individual components of the immune complexes to be identified. This method is ideal fot the investigation of the composition of immune complexes in the serum of patients with PMR/GCAO as the IC present are only raised before steroid therapy and thereafter usually fall rapidly. Conf sequently only small amounts of sera containing Is are available for analysis. Pretreatment or firs: treatment samples were taken and assayed for IC bo three independent methods. Only those sers containing raised IC by two or three of these methods were analysed further. The IC isolatef contained a mixture of immunoglobulins, comple ment components, acute phase proteins, anฮึ proteinase inhibitors.

All the IC investigated contained IgM but only few contained $\mathrm{IgG}$, and both of these immung globulins can activate the classical complement pathway. IgA was present in more IC than IgG, and although IgA does not activate the classical comple ment pathway, some subclasses can activate the alternative complement pathway.

A number of complement components were present in the IC. $\mathrm{C} 1 \mathrm{q}$ was obviously present in ald samples where the anti-C1q affinity adsorbent was used to purify the complexes and was also present in most of the complexes purified by the anti-C3 30 Sepharose adsorbent. C1r, C1s, C3, and C4 we also present in many samples. $\mathrm{C} 1$ esterase inhibita (C1 activator), which binds tightly and rapidly to cause dissociation of $\mathrm{C} 1 \mathrm{r}$ and C1s from the IC, ${ }^{21}$ was also found and tended to be more common patients with PMR. Factor $B^{22}$ was identified in on three IC, all purified with anti-C3c-Sepharose. the alternative complement pathway it forms the convertase $\mathrm{C} 3 \mathrm{bBb}$ with activated $\mathrm{C} 3$ (C3b Properdin, which binds to $\mathrm{C} 3 \mathrm{~b}$ and stabilises the 
$\mathrm{C} 3 \mathrm{bBb}$ complex and maintains the $\mathrm{C} 3 \mathrm{~b}$ positive feedback loop, ${ }^{23}$ was found in nine IC.

Factor $\mathrm{H}$ was identified in several IC, it is a control protein for the classical and alternative complement pathways, potentiating the action of $\mathrm{C} 3 \mathrm{~b}$ inactivator on $\mathrm{C} 3 \mathrm{~b}$ while preventing the binding of other proteins to C3b. ${ }^{24}$ Two IC contained both factor $\mathrm{H}$ and properdin.

Other investigations of IC components showed CRP was present in all the IC studied. CRP is an acute phase protein, which is raised in untreated PMR and GCA, and it has been suggested that CRP may be capable of inhibiting alternative complement pathway activation ${ }^{25}$ and stopping $\mathrm{C} 3 \mathrm{~b}$ binding to surfaces. $\alpha_{2}$ Macroglobulin, a serum protease inhibitor, was found in some IC, which might suggest that these complexes are in the process of inactivation and are therefore inert.

It is possible that some serum components could bind non-specifically to the IgG-Sepharose (e.g., $\mathrm{Clq}$ or rheumatoid factor) via the Fc portion of the coupled IgG. Obviously the use of $(\mathrm{Fab})_{2}$ antibodies would overcome this problem. The levels of noncomplexed Fc binding materials, however, are minimised by the PEG precipitation and washing, and we have not found that PMR/GCA sera contain raised levels of rheumatoid factor.

There are some differences in the components identified in IC purified using the different affinity matrices. This was expected and is likely to reflect differences in the degree of complement activation, the complement activation pathway, the presence of inhibitors, ${ }^{21} 2627$ the degree of solubilisation, and differences in the removal of the complexes. 2829

There were also some differences between those patients who had polymyalgia rheumatica only and those who had giant cell arteritis. The presence or number, or both, of the polypeptide chains of $\mathrm{C} 1 \mathrm{r}$, $\mathrm{C} 1 \mathrm{~s}, \mathrm{C} 1 \mathrm{q}, \mathrm{C} 3$ and $\mathrm{C} 4$, properdin, factor $\mathrm{B}, \alpha_{2} \mathrm{M}$, factor $\mathrm{H}$, and $\mathrm{Cl}$ esterase inhibitor appeared to be different, though it was hard to determine the significance of these differences or draw any firm conclusions because of the small numbers. The IC in PMR and GCA differed from the IC previously analysed by the same method, in the sera of patients with rheumatoid arthritis ${ }^{1}$ as the RA IC did not contain properdin and factor $\mathrm{B}$, and had a population purified by anti-C1q-Sepharose unable to activate the classical complement pathway indicated by the absence of $\mathrm{C} 3$ and the presence in only $1 / 7$ IC of $\mathrm{Clr}$ or C1s.

The present study indicates that the method we have developed allows the rapid and reproducible analysis of immune complexes in multiple samples which are available in small amounts. In addition, it is possible to separate the immune complexes by this method and store nitrocellulose strips to allow identification of further components as new antisera become available.

\section{References}

1 Smith A J. Cawston T E. Hazleman B L. A rapid and reproducible method for the analysis of immune complexes using affinity chromatography and Western Blotting. J Immunol Methods 1985; 84: 125-34.

2 Malmvall B E. Bengtsson B A. Kaijser B. Nilsson L A. Alestig $\mathrm{K}$. Serum levels of immunoglobulin and complement in giant cell arteritis. JAMA 1976: 236: 1876-8.

3 Park J R. Jones J G. Hazleman B L. Relationship of the erythrocyte sedimentation rate to acute phase proteins in polymyalgia rheumatica and giant cell arteritis. Ann Rheum Dis 1981; 40: 493-5.

4 Park J R. Jones J G. Harkiss GD. Hazleman BL. Circulating immune complexes in polymyalgia rheumatica and giant cell arteritis. Ann Rheum Dis 1981: 40: 360-5.

5 Espinoza L R. Bridgeford P. Lowenstein M. Bocanegra T S. Vasey F B. Germain B F. Polymyalgia rheumatica and giant cell arteritis: circulating immune complexes. J Rheumatol 1982: 9: 556-60.

6 Malmvall B E. Bengtsson B A. Nilsson L A. Bjusten L M. Immune complexes. rheumatoid factors and cellular immunological parameters in patients with giant cell arteritis. Anm Rheum Dis 1981; 40: 276-80.

7 Papaioannou C C. Gupta R C. Hunder G G. McDuffie F C. Circulating immune complexes in giant cell arteritis and polymyalgia rheumatica. Arthritis Rheum 1980; 23: 1021-5.

8 Liang G C. Simkin P A. Mannik M. Immunoglobulins in temporal arteries: an immunofluorescent study. Ann Intern Med 1971: 81: 19-24.

9 Waaler E. Tonder O. Milde E J. Immunological and histological studies of temporal arteries from patients with temporal arteritis and/or polymyalgia rheumatica. Acta Pathol Microbiol Immunol Scand [A] 1976: 84: 55-63.

10 Park J R, Hazleman B L. Immunological and histological study of temporal arteritis. Ann Rheum Dis 1978; 37: 238-43.

11 Jones J G. Hazleman B L. Prognosis and management of polymyalgia rheumatica. Ann Rheum Dis 1981; 40: 1-5.

12 Zubler R H. Lange G. Lambert P H. Miescher P A. Detection of immune complexes in unheated sera by a modified ${ }^{125} \mathrm{I}-\mathrm{Clq}$ binding test. J Immunol 1976; 116: 232-5.

13 Harkiss G D. Brown D L. Detection of immune complexes by a new assay, the polyethylene glycol precipitation-complement consumption (PEG-CC) assay. Clin Exp Immunol 1979; 36: 117-29.

14 Digeon M. Laver M. Riza J. Bach J F. Detection of circulating immune complexes in human sera by simplied assays with polyethylene glycol. J Immunol Methods 1977: 16: 165-83.

15 Laemmli U K. Favre M. Maturation of the head of bacteriophage T4-1. DNA packaging events. J Mol Biol 1973: 80: 575-99.

16 Bolton A E. Hunter W M. The labelling of proteins to high specific radioactivities by conjugation to a ${ }^{125} I$ containing acylating agent. Biochem $J$ 1973; 133: 529-39.

17 Diezel W. Kopperschlagier G. Hoffman E. An improved procedure for protein staining in polyacrylamide gels with a new type of Coomassie brilliant blue. Anal Biochem 1972; 48: 617-20.

18 Towbin H. Staehelin T. Gordon J. Electrophoretic transfer of proteins from polyacrylamide gels to nitrocellulose sheets: procedure and some applications. Proc Natl Acad Sci USA 1979; 76: 4350-4.

19 Male I. Roitt I M, Hay F C. Analysis of immune complexes in synovial effusions of patients with rheumatoid arthritis. Clin Exp Immunol 1980; 39: 297-300. 
20 Per S R. Abruzzo J L. Heimer R. Analysis of immune complexes by two-dimensional gel electrophoresis. Clin Immunol limmumopathol 1985: 34: 165-73.

21 Sim R B. Reboul A. Preparation and properties of human CT inhibitor. Methods Enzymol 1981: 80: 43-54.

22 Kerr M A. Human Factor B. Methods Enzymol 1981: 80: $102-12$.

23 Reid K B M. Preparation of human properdin. Methods Enzymol 1981: 80: 143-50.

24 Whaley K. Ruddy S. Modulation of the alternative complement pathway by $\beta 11$ globulin. J Exp Med 1976: 144: 1147-63.

25 Mold $\dot{C}$. Gewurz H. Inhibition effect of C-reactive protein on alternative complement pathway activation by lysosomes an streptococcus pneumoniac. J Immunol 1981: 125: 2089-92

26 Fujita T. Gigli I. Nussensweig V. Human C4 binding protein If role in proteolysis of $\mathrm{C}$ th by $\mathrm{C} 3 \mathrm{~b}$-inactivator. $J$ Exp Med $197 \mathrm{~W}$ 148: $1044-51$.

27 Press E M. Gagnon J. Human complement component C $\frac{6}{6}$ Structural studies on the fragments derived from $\mathrm{C}^{4} \mathrm{~h}$ b cleavage with C.3b inactivator. Biochem J 1981: 199: 315-57. $\overrightarrow{\mathbb{D}}$

28 Takahashi M. Tack B F. Nussensweig V. Requirements for thळ solubilisation of immunc complexes by complement. J Exp Me 1977: 145: 86-100.

29 Hughes-Jones $N$. Complement solubilisation of immun $\overrightarrow{0}$ complexes. Immunol Todar 1982; 3: 156-7. 